\title{
Research on the Reform of Physical Fitness Training Curriculum in China's Police Colleges and Universities
}

\author{
ZHANG Fan $^{1,2} *$ \\ ${ }^{1}$ Department of Police Skills and Tactics, Nanjing Forest \\ Police College \\ ${ }^{2}$ Sports Science postdoctoral programme, Nanjing Normal \\ University \\ Nanjing 210023, China \\ zhangfan@nfpc.edu.cn
}

\author{
ZHOU Bo \\ Department of Police Skills and Tactics \\ Nanjing Forest Police College \\ Nanjing 210023, China
}

\author{
JIA Chang-zhi \\ Department of Police Skills and Tactics \\ Nanjing Forest Police College \\ Nanjing 210023, China
}

\begin{abstract}
At present, police colleges and universities in China have carried out police physical fitness courses. Although the teaching objectives and tasks are similar, the quality of teaching is quite different, and there are many problems. For example, physical education curriculum construction lags behind; teaching methods and means are too single; teaching effectiveness is not good; physical education curriculum is not enough; it does not conform to the law of sports training. As the physical condition is not only the basis of police skills and tactics, but also the important organic part of combat ability. Therefore, the overall health status of the police team needs to be improved. Based on a comprehensive analysis of the status quo of the police physical fitness curriculum, this paper puts forward some strategies and suggestions for the weak link of the police physical fitness, which will provide a reference for the reform of the police physical fitness curriculum.
\end{abstract}

Keywords-Police colleges; Physical fitness training; Curriculum reform; Police Skills and Tactics

\section{INTRODUCTION}

At present, most of the Chinese police colleges have no special physical effective training theory or methods, many of which are used in military academies and institutes of physical education training plan, and employ army instructors or sports coaches to guide police training. Sport institutions follow the rules of competitive sports, and strive to train students to master the relevant principles and methods of sports technology, and on this basis to practice. The purpose of military physical fitness training is to enhance the individual combat ability of soldiers in the field. These two kinds of physical fitness training purposes and methods are different from the police physical fitness training. Therefore, according to the needs of the future police career, it is necessary to study the physical fitness training system of Police College in China.

\section{CurRent Situation OF Physical FitNess Training In CHINA Police College}

As a public security organ to safeguard the stability of the state and society, the mission of the police is sacred and the task is arduous. The essential condition for the police to accomplish this sacred and arduous mission is to have excellent physical qualities. Some Chinese police colleges do not pay attention to their physical fitness training, the consequences are obvious - some professional police are unable to perform their duties to maintain social stability and protect people's lives and property because of physical disability. The following are the main problems.

\section{A. Some misunderstandings about physical fitness training}

Police College Physical fitness training has two problems: (1) lack of physical fitness training time to complete the teaching plan taught to the students, (2) some of the colleges tend to capture, China boxing and other tactical training courses instead of physical fitness training. Even some students believe that tactics and skills training can replace specific physical fitness training [1]. The problem is that we cannot realize the support function of physical ability for the mastery and application of skills and tactics. Because there is no effective physical fitness as a support, then superb skills and tactics cannot fully play its due role.

\section{B. Blind transplantation of physical fitness training methods}

In the police college, most of the instructors are from the sports institutes or the military academies. In the course of physical fitness training, instructors will automatically transplant sports or military physical fitness training methods; there is a deviation from the characteristics of police physical fitness training and disconnection problems. Such as a strength training method is still a few commonly used barbell training, 
long-term training in this form, will result in students at the same time bearing capacity rise, agility coordination ability decline. In speed training content, including starting, acceleration, sprint running, this is basically training method followed sports, which cannot form the reaction speed of police during the mission.

\section{Physical fitness training is not up to standard}

Through long-term and systematic training, we can achieve the effect of improving physical fitness at a stage [2-3]. On this basis, through repeated training, we can finally achieve the leap from quantity accumulation to quality. On the other hand, if there is a lack of systematic and definite physical fitness training, then everything is an empty talk. Some Police College pays more attention to the study of the theoretical basis and not enough attention to physical fitness training. In the very limited time, only to impart some basic training methods and no spare time to organize training. Lack of training results in the physical deterioration of many students, and even physical fitness is not up to standard.

\section{The means of physical fitness training are monotonous}

In the course of physical fitness training in Police College, the training methods are monotonous due to the restriction of equipment and field, and even the training methods have not changed in one academic year or even during the whole school period. Physical fitness training is relatively boring and lack of entertainment, in this case, if the training methods are too monotonous, it is easy to make students tired and fatigue.

\section{INFLUENCING FACTORS OF PHYSICAL FITNESS Training in China Police College}

\section{A. Student factors}

Students in Police College have different physical qualities when they enter school. Some of them are more comprehensive, and some of them are more prominent in one respect. One is the physical basis of physical fitness training, physical difference makes the traditional teaching method is very difficult to give consideration to each individual, and for each student physical fitness training attitude is different, the effect of physical fitness training cannot be guaranteed.

\section{B. Instructor factors}

Students' Physical fitness training in Police College includes both the trainee's practice and the teacher's training. Some students do not possess special physical fitness training and physical fitness training before entering school, and they know little about physical fitness training. Therefore, their training effect in the physical fitness training course is dependent upon the training ability of the instructor. Therefore, the instructor in charge of police school physical fitness training should have good comprehensive qualities (including professional teaching experience and excellent). Training schedule and content should be reasonable, and the use of scientific training methods, to guide the students to devote themselves to physical fitness training, but also to pay attention to the restoration of fatigue after training.

\section{College factors}

In order to achieve the expected goal of physical fitness training, in addition to the joint efforts of teachers and students, good physical environmental conditions are also indispensable. Physical fitness training related material environment includes wide area, complete with professional equipment, the use of teaching materials, teaching schedule and other content. They are the basic guarantee for the trainees to improve their training effect, which needs high attention from Police College.

\section{Discuss THE DEVELOPMENT COUNTERMEASURES OF} Physical Fitness Training Course in Police Colleges

\section{A. Implementation stratified teaching of physical fitness training course in Police College}

Carrying out the stratified teaching of physical fitness training courses in Police College, is based on the consideration of the students' quality difference in physical fitness training. For example, to stimulate students' intrinsic motivation as the goal, to mobilize the enthusiasm of learning, give full play to the main role, to change the previous physical fitness training course mode of "passive practice" to "active practice" [4].

Before the implementation of stratified teaching in Police College, teachers are required to conduct a special test on students, and judge the level of students, according to the test results and the usual training conditions of students. Note that, in the process of physical fitness training carried out, teachers should keep track of different students' training, regular periodic inspection, according to the dynamic information in a timely manner to adjust the level of students, improve their training enthusiasm and ensure the training effect. In the process of classroom teaching, the teacher should design the teaching content, different levels according to different characteristics of students, so that students can learn in accordance with their ability of teaching progress, step by step to lay a solid foundation. In addition, teachers should be committed to building a modern democratic and harmonious relationship between teachers and students. The teacher should give timely guidance to students and help them build up confidence, and prevent students get disheartened and big with pride phenomenon. At the end of the education task, teachers should do all kinds of data collection and data processing in time to be prepared for the next phase of the task.

Through carrying out the stratified education in the physical fitness training curriculum, not only can help to arouse the interest of the students at different levels, to improve the learning effect, but also has a positive role in promoting the teachers. The implementation of Stratified schooling, teachers prepare lessons, lectures, guidance, layout and other teaching tasks increased significantly, but in this process, the initiative of teachers can be transferred, the level of teaching can also be improved. Therefore, implementation of Stratified education in the physical fitness training courses in police colleges can benefit both teachers and students. 


\section{B. Deepening the understanding of police physical fitness training}

In the process of physical fitness training education in police colleges, teacher must clearly recognize that physical fitness training is not only to the physical ability standard (or qualified). More important is to enhance the soft power of the students, in the future to prepare for the police career [5]. The police soft power is the comprehensive embodiment of the police team's spiritual realm, ideological and moral level, cultural accomplishment, practical combat skills (including physical ability), and reflects the public image of the people's police force. In order to gain public recognition, the police force must show strict organizational discipline and the ability to prevent and combat crime, which are closely related to the physical condition of the police themselves. Good physical condition enables the police can adapt to all kinds of harsh and complex environments and effectively reduces injuries and sacrifices in precarious situations. Therefore, carrying out physical fitness training in police colleges is an important way to improve the soft power of the police force.

\section{Improving physical fitness training methods and patterns}

In the curriculum of physical fitness training in police colleges, scientific and systematic physical fitness training modes and methods should be specified. (1) Establish a stable pattern, includes course time arrangement and the use of teaching materials, teacher training, equipped with goals (such as physical fitness training arrangements in the afternoon or evening, without affecting other theoretical courses to learn).(2) Arrange routine exercises and physical fitness training in the morning, the contents of the tests include personnel standards. Through low load training to restore physical fitness, teachers can optimize the discipline style of students, and promote the physical quality of students. (3) Practice police skills in combat and other skills and tactics. Appropriate technical and tactical qualities are essential to the police, but their level of play is based on physical fitness. Therefore, the interaction between combat training and physical fitness training can promote each other.

\section{Improving the facilities related to physical fitness training in Police Colleges}

Physical fitness training facilities in police colleges mainly deal with such skills as fighting, shooting and so on. The facilities used for physical fitness training are relatively few and need to be further strengthened and improved [6]. For example, in terms of strength training, in addition to basic dumbbells and barbells and other equipment, should also be further added bench press frame, jerk of the training table, strength training units and other equipment, in order to enrich the physical fitness training and increase the fun of physical fitness training.

\section{E. Improving the physical instructor and student assessment system in Police College}

In order to ensure that the physical fitness training of public security institutions be effective, we should improve the assessment system of teachers and students.(1) Professional knowledge and teaching initiative of physical instructor will directly influence the effect of physical fitness training [7]. On the one hand, colleges should train specialized physical instructor in a planned and batch way to improve their professional accomplishment in physical fitness training. On the other hand, the teaching methods and effects of instructor are periodically tested and evaluated to stimulate their initiative in teaching, and (2) some students in police colleges do not pay enough attention to physical fitness training during school, and they seldom participate in it, which eventually resulting in no graduation. Therefore, Police College should increase their physical test to make students whose physical condition is poor have a sense of crisis, and pay more attention to physical fitness training.

\section{F. Set up special police physical fitness training materials}

Most police colleges in China have been using the old sports teaching materials, in which the content of physical fitness training is too little, so that education cannot be carried out according to the theory of physical fitness training. In order to solve this problem, China police colleges should actively organize professional scholars to rewrite textbooks for students' physical fitness training. When compiling textbooks, we should pay attention to: (1) teachers should be scientific and systematic in developing physical fitness training for students. (2) Preparation of teaching materials should be open, pay attention to strengthen communication and communication with other institutions, and take advantage of other people's strengths to make up the shortcomings. (3) The preparation of teaching materials should also consider the various software and hardware conditions of the school itself, as well as the students' physical ability, hobbies and so on. In addition, police colleges and universities can also appropriately arrange for students and teachers participate in the development and preparation of physical fitness textbooks, to ensure that the teaching materials are more targeted and more in line with the actual situation and requirements of students.

\section{G. The content of physical fitness training should be in line with students' network life}

With the rapid development of information technology, a variety of advanced multimedia and Internet technology and equipment have been extensively used in school teaching, which makes physical education full of vigor and vitality. Depending on the requirements of students, physical instructor should combine their physical fitness training with the network so as to fully arouse their interest and enthusiasm [8]. Teachers can through the network of social media to answer physical fitness training problems of real-time encountered by students, and through the network video to give some guidance to the students, that they can avoid detours and quickly enhance physical fitness.

\section{CONCLUSION}

The China Police College's goal is to provide qualified police personnel, and police college physical fitness training class, for students in the days after the job really takes the responsibility to defend the safety of people's life and property. A qualified policeman should not be merely an armchair strategist, but should have the ability to defeat suspects. Most of the acquisition of this ability come from the systematic and scientific physical fitness training courses set up by police colleges. The physical fitness training courses set by police 
colleges are aimed at physical fitness and, more importantly, good physical fitness, which is determined by the special nature of the police. Therefore, police colleges and universities should arrange the students' physical fitness training courses and patterns reasonably, so as to the excellent police talents continuously.

\section{ACKNOWLEDGMENT}

This work was supported in part by the Project of the Fundamental Research Funds for the Central Universities under Grant LGZD201709, in part by the Project of China Postdoctoral Science Foundation under Grant 2017M611849, in part by Jiangsu Qing LAN Project under Grant 2017, and in part by Nanjing Forest police College Teaching Reform Project under Grant ZD17001 \& YB17001.

\section{REFERENCES}

[1] Cao Chao. Study on the physical fitness training of police. Proceedings of the Military Institute of sports, vol. 26, pp. 50-52, April 2007. (In Chinese)

[2] Chen Yun. On the endurance quality training of police college students. Journal of Guizhou Police Officer Vocational College, vol. 18, pp. 94-96, May 2006. (In Chinese)

[3] Zhu Leisheng. The police college freshmen physical fitness training teaching plan design. Journal of political science and law, vol. 22, pp. 117-118, March 2005. (In Chinese)

[4] Liu Yu. Study on the problems and Countermeasures of physical fitness training for police officers. Journal of sports science and technology, vol 4, pp. 197-198, March 2014. (In Chinese)

[5] Liang Jianjun. The Police College of physical fitness training. Journal of political science and law, vol. 29, pp. 124-126, June 2012. (In Chinese)

[6] Liu Fushun. Study on the current situation and Countermeasures of independent physical fitness training for police college students. Journal of contemporary sports science and technology, vol. 33, pp. 26-27, March 2013. (In Chinese)

[7] Ouyang Hong. On the physical fitness training of students in Police Colleges. Journal of Jiangxi Jouth Vocational College, vol. 20, pp. 94-95, February 2010. (In Chinese)

[8] Chen Yun. On the endurance quality training of police college students. Journal of Guizhou Police Officer Vocational College, vol. 18, pp. 94-96, May 2010. (In Chinese) 